\section{APLICACION DEL DERECHO TRIBUTARIO EN MATERIA ADUANERA}

\author{
CPC FERNANDO COSÍO JARA
}

El Derecho Tributario es el conjunto de normas que regulan el tributo. entendido como una fuente de recursos públicos destinados a financiar los gastos que cubrirán el costo de los servicios necesarios para satisfacer las necesidades públicas.

Es una de las funciones principales de Aduana, no la única, la recaudación del tributo aduanero (no olvidemos su función de control relacionada con medidas de orden público, sanidad, defensa del consumidor y del patrimonio cultural). El Derecho Aduanero guarda una notable interrelación con el Derecho Tributario, que ha llevado a Anabalón y a un grueso sector de la doctrina a hablar de Derecho Tributario Aduanero.

Por ello, dentro del Derecho Aduanero se van a estudiar temas propios del Derecho Tributario, como el de la obligación tributario-aduanera, su nacimiento y extinción, lo que nos lleva al estudio de la naturaleza jurídica del tributo aduanero, que exige partir de los conceptos de tributo e impuesto, tomando en cuenta que impuesto es el tributo cuyo cumplimiento no origina contraprestación directa en favor del contribuyente, y que en materia aduanera está presente en el denominado Derecho Advalorem CIF, el
Impuesto General a las Ventas y el Impuesto Selectivo al Consumo, que se originan como consecuencia de un régimen de importación definitiva.

Por su parte, la tasa y la contribución son tributos vinculados con el contribuyente, estando presentes las primeras en materia aduanera (sobretasas agropecuarias, tasas por servicios extraordinarios y otras).

Por otro lado, existen figuras aduaneras asimilables a sus similares tributarias, como la liquidación de cobranza derivada de una importación a la orden de pago y el cargo por ajuste de valor a la resolución de determinación.

Los Principios Tributarios Nota distintiva del Derecho Aduanero y el Tributario lo constituye el hecho de que los principios tributarios no son aplicables en todos los casos a la materia aduanera; así el propio Principio de Legalidad de la Tributación, "no hay tributo sin ley", se encuentra erosionado en materia de aranceles, donde la vía para establecerlos es el decreto supremo.

Esta excepción al Non taxation without representation se origina. como afirma Hernández Berenguel, por el hecho de que los avances tecnológicos impresionantes dan origen a la aparición y comercialización de mercancías y crean la necesidad de asignarles nuevas partidas y derechos arancelarios, lo cual requiere de respuestas inmediatas que sólo el Ejecutivo está en capacidad de satisfacer.

En cuanto al Principio de No Confiscatoriedad, éste no rige porque no se aplica para los impuestos indirectos y el derecho aduanero en esencia, vale decir el ad valorem, tiene esta naturaleza (el 
comiso no viola este principio porque no recae en la totalidad de los bienes de una persona sino sobre bienes individualizados, tratándose finalmente de una sanción no a la persona sino a la mercadería).

Como parte del proceso de unificación de las administraciones tributarias, la nueva ley peruana señala que en determinadas materias hay una aplicación inmediata y no supletoria del Código Tributario.

Aplicación del Codex.- A su vez, la ley señala los casos de aplicación supletoria del Código Tributario (Disposición Complementaria Primera), como sucede cuando un mismo hecho puede ser objeto de dos sanciones, situación no prevista en el ordenamiento aduanero, pero señalado en el artículo 171 de la norma impositiva (se aplica la sanción más grave).

Como parte del proceso de unificación de las administraciones tributarias, la nueva ley peruana señala que en determinadas materias hay una aplicación inmediata y no supletoria del Código Tributario, estableciendo normas de envío respecto a temas como interés moratorio (artículo 11 de la ley), extinción de la obligación tributario-aduanera (artículo 20 de la norma) y en los procedimientos de devolución (artículo 24 del reglamento) y reclamación (artículo 111 de la ley), aunque con excepciones, como la inaplicación de la regla solve et repete

(paga y después reclama) como criterio general.

\section{CONCLUSION}

Por lo expuesto, la influencia del Derecho Tributario en materia aduanera es notoria, lo cual no resulta, sin embargo, suficiente para negar la autonomía del Derecho Aduanero.

Después de todo, el hecho de que existan instituciones y procedimientos comunes va de la mano con la idea de que el Derecho es uno solo y todas sus ramas provienen de un tronco común. 